\title{
BEYOND IDEOLOGIES: THE MEANING OF LIFE IN THE HISTORICAL AND PSYCHOLOGICAL PERSPECTIVE
}

\author{
Akop P. Nazaretyan \\ Institute for Oriental Studies, Russian Academy of Sciences \\ Moscow
}

\begin{abstract}
Throughout human history, in-group solidarity has been achieved at the price of confrontation with out-group individuals ("them vs. us" mental scheme); this has been guaranteed by religious or quasi-religious ideologies. However, in compliance with some basic evolutionary patterns, the traditional mechanism of social aggression-regulation is actually becoming counter-productive and threatens to destroy planetary civilization during the next decades. The author argues that the perspectives of global viability essentially depend on whether or not the human mind develops new mechanisms of strategic meaning-construction and solidarity regardless of large-group (confessional, national or class) mythologies.
\end{abstract}

Keywords: crisis, civilization, techno-humanitarian balance, worldview, meaning of life, ideology, religion, knowledge-enabled destruction, Anthropic principle, synergetics, universal natural selection.

Discussions related to the perspectives of global civilization show a growing agreement about at least one point. Namely, global problems are a complex mixture of cultural and psychological factors, such as worldviews, thought processes, and dominant value systems. This consensus is supported by historical experience, which discovers numerous examples of crises caused by human activity. A survey of such precedents helps us to identify some patterns that can be used to provide predictive models for the future of humanity.

The subject-matter of this paper has been taking shape simultaneously with evolutionary mechanisms discovered by interdisciplinary re-

The work is supported by the Russian Foundation for Humanities. I deeply appreciate the comments by Prof. Alexander Panov (Moscow State University), Prof. Graeme Snooks (Australian National University) and especially Prof. Barry Rodrigue (University of Southern Maine) on this paper. 
searches coming into focus as a result of Big (Universal) History and synergetic (chaos theory) paradigms. ${ }^{1}$ To substantiate the final arguments, the first six sections of the article briefly present the identified mechanisms; for illustration of these mechanisms and a detailed bibliography see (Nazaretyan, 1991; 2004; 2005b; 2008; 2009b).

\section{The concept of crisis. The Law of delayed dysfunction and the Rule of redundant variety}

From a synergetic perspective, living organisms exist as systems in sustainable non-equilibrium, continuously working against equilibrating (destructive) pressures from the environment, in order to sustain their integrity. Such anti-entropy work requires regular consumption of energy from outside the system, which comes at the price of other systems' destruction. The competition for free energy is the premise for the formation of multi-stage and multi-dimensional natural symbioses, which build and maintain global energy circulation.

This dialectics of construction and destruction is what makes longterm linear processes in non-equilibrium systems impossible. New external or internal conditions develop, which results in anti-entropy activity turning into increasing entropic effects. These transitional phases are called crises. A crisis is followed either by a catastrophic phase (system destruction), or by change of the habitat, or by updating the system's anti-entropy mechanisms.

There are multiple criteria for the classification of crises. Local, regional, and global crises can be distinguished by their scale, although in some cases, a regional crisis can become global because of its role in the evolution. Similarly, a crisis can be ecological or geopolitical (in social systems) while they are often complex and interrelated. Therefore, we mostly distinguish crises by sequences of events.

\footnotetext{
1 Big History, Universal History, Mega-History and Weltallgeschichte are the terms (in various national traditions) for the single cross-disciplinary model of evolution involving its cosmological, geological, biological pre-social and social stages. Synergetics, chaos theory, theory of dissipative structures and nonlinear non-equilibrium thermodynamics are the designations of the single model of self-organization and sustainable non-equilibrium involving relevant processes in physics, chemistry, biology, anthropology, sociology, and psychology.
} 
As to their genesis, we distinguish between exogenous, endogenous and endo-exogenous crises. Exogenous crises are due to relatively accidental changes in the habitat, independent from the system's activity. These can include fluctuations in solar or geological activity, spontaneous climatic changes, cosmic cataclysms, or emergence of new warrior nomads. Endogenous crises result from transitions in the stages of the genetic program or its exhaustion (like aging of a multicellular organism). Crises of the third (mixed) type are consequences of the unfavorable habitat transformations which have been provoked by the system's own activity.

Endo-exogenous crises are the ones that have played the most essential and creative role in the evolution of nature and society, and they are of special interest both for the synergetic theory and for the world's current situation. Gradual increase of anti-entropy activities (for instance, growing biological population and resource consumption) accumulates destructive effects in the system's environment, resulting in former mechanisms of life sustenance becoming counter-productive. The Law of delayed dysfunction states that such a phase is inevitable, and further survival of the non-equilibrium system depends on its ability to transform. If it has no opportunity to change its habitat, it will either collapse or develop new anti-entropy mechanisms that furnish higher specific productivity (the ratio of the useful product to the volume of destruction). This scenario always requires radical increase in organizational complexity and "intelligence."

The chance to constructively overcome a crisis is related to the amount of redundant variety that the system may have accumulated in relatively secure earlier stages. If the selective process has not been rigid enough to discard what geneticists call slightly deleterious mutations, then marginal elements that have earlier been actually useless and played a peripheral role might provide the system with the internal resources of diversity to develop new survival patterns. This obviously particularizes the Law of requisite variety formulated by W.R. Ashby (1964) (see section 3).

To illustrate these two propositions - the Law of delayed dysfunction and the Rule of redundant variety - I would like to mention, by way of example, an episode from the early history of the biosphere.

Over a period of billions of years, early life on Earth existed mostly as cyanobacteriae (blue-green algae). Their waste product - oxygen - ac- 
cumulated in the atmosphere and changed its chemical composition. As a result, the atmosphere was strongly oxidized, which in turn led to a mass extinction of the cyanobacteriae.

Meanwhile, by that time, a new kind of protozoa had emerged through the process of mutations - those that consumed oxygen and produced carbon dioxide. Under the new atmospheric conditions, these organisms started to breed extensively and got the leading role in the evolution of life. In turn, the biosphere became radically more complex, which resulted in higher dynamic sustainability.

Five global breakthroughs, following similar scenarios, have been described by paleontologists in the biological history of the present Phanerozoic Eon (although the factors are not so clearly revealed in each case). Historical sociologists, for their part, have described no less than seven such breakthroughs in social prehistory and history. In order to understand the latest ones, we need to add another essential concept, which I will cover in the next section.

\section{Anthropogenic crises.}

\section{The Law of techno-humanitarian balance}

Endo-exogenous crises became anthropogenic at the pre-social stage of evolution, when the first pebble tools (choppers) were developed about 2.5 million years ago in Africa. These tool-makers - Homo habilis - inhabited the region of Olduvai Gorge (Tanzania) and occupied a neophron niche in the ecosystem.

Archeologists suggest that the choppers' functions were to drive away predators from their prey, to peel off remnant meat after the prey was consumed by other predators, to break skeleton bones and skulls for extracting marrow and brain, and to struggle against rivals in their ecological niches. What matters for anthropologists is that all Homo habilis skull fragments show evidence of artificial damage, which indicates that the original tool-makers might have used the choppers to fight among themselves.

Thus the Rule of ethological balance (a balance between natural weapons of a species, such as fangs or hoofs etc., and its instinctive inhibition against intra-species aggression, which sustains viability of animal populations), has been broken once and for all at an early stage of Homo genus formation. As the Russian proverb states, "A raven will not peck out 
another raven's eye" (this is true at least in an ordinary ecological situation), whereas a dove can long and cruelly finish off its weaker congener (Lorenz, 1981): lacking the instruments for quick and effective killing, the dove unlike the raven does not need aggression-inhibition. Therefore, an imaginary flock of doves with hawk's beaks would not be viable because of excessively high portion of mortal conflicts.

However, the strange $H$. habilis species looks like just such a zoological chimera. Habilis lacked natural weapons and, therefore, their instinctive aggression-inhibition was not adequate to the new instruments for killing. The combination of psychology of an armless animal with dangerous artificial weapons doomed them to self-destruction. This collision in human prehistory has been called the existential crisis of anthropogenesis.

Apparently, most populations could not cope with such a menace. As the German anthropologist F. Klix (1983) put it, the boundary between animals and proto-humans was more than once approached but rarely crossed. Yet, at least one habilis population did survive and started a new spire of evolution on Earth. The most developed hypothesis to explain how the first Homo managed this feat attributes it to the emergence of an extra-natural aggression-inhibitor conditioned by necrophobia. The rudiments of animistic thinking entailed ascribing to the dead individual the ability to revenge himself upon the offender. This on the one hand restricted aggression among the kinsmen and on the other, stimulated taking biologically senseless care of handicapped individuals (the first archeological evidence of this appears in the Lower Paleolithic). The neurotic fear replaced the insufficient instinct in its balancing function and eventually became ferment for spiritual culture (Nazaretyan, 2005a).

Since that time, the existence of hominids, including our species, has not had natural guarantees; viability of their communities has depended on the parity between instrumental ${ }^{2}$ and self-controlling attributes of their cultures. The analysis of many anthropogenic crises and catastrophes in various historical epochs and on various continents has discovered a systemic dependency between three variables: technological potential, quality of cultural regulation and internal sustainability of

2 Instrumental (culture, intelligence) here and below refers to technologies and abilities to handle them. 
society. The Law of techno-humanitarian balance claims that the higher the power of production and war technologies are, the more advanced behavior-restraint is required to ensure the self-preservation of society.

The formal apparatus of the model (see Nazaretyan, 2008; 2009b) demonstrates that a growing technological potential increases society's external sustainability (its independence from spontaneous natural or geopolitical cataclysms); we can confirm this, for example, by comparing human losses during the natural hazards in different regions (White, 1974). At the same time, the system becomes more vulnerable to mass emotional fluctuations, to impulsive decisions of authoritarian leaders, etc. In other words, a society's internal sustainability decreases if its strength is not compensated by adequate development of values and norms.

In real history, new technologies usually gave people a sense of omnipotence and impunity, as well as an irrational drive to engage in "small victorious wars" against nature or neighboring societies (a mass complex of catastrophophilia, a term coined by the Dutch political scientist P. Sloterdijk (1983)). At large, we have described this typical state of minds as Homo prae-crisimos syndrome, which is often brought about by the disparity between instrumental and humanitarian intelligence; this syndrome accompanies a social system's violent extensive development.

Sooner or later, the society infected with the pre-crisis euphoria destroys the natural and / or organizational bases of its existence. Many oases of civilization on different continents of Earth have fallen victim to their own imbalanced might: flourishing societies experienced "fracture and breakup," often happening unexpectedly for their contemporaries, as well as for later historians. Historical, geographical, and ethnographical literature is full of stories, which have followed similar scenarios.

Here is a typical tragic episode from the recent past.

In the mid 1970s, soon after the Vietnam War, observers noticed the disappearance of a Mountain Khmer tribe, which had traditionally inhabited the Vietnamese territory. An international scientific expedition found that tribal hunters had fallen victim to their own short-sightedness. Having learned how to use the US M-16 rifles, they quickly exterminated local fauna and shot each other, while those few who survived left the mountains and lost themselves by drinking and the like. 
Many similar events have happened during the past two centuries in various parts of Africa, Asia, Australia, and the Americas. They looked like "artifacts", as the technologies had come from outside, the archaic societies had skipped over several historical phases, and left a deep gap between firearm use, for example, and Stone Age psychology; therefore, the processes were accelerated, and easily reconstructed. In large-scale history, as technologies emerged inside the society, compatible causalities were delayed for centuries or, in early epochs, for millennia.

Fortunately, however, we see alternative scenarios occur in history as well. For example, if a society having exhausted the resources of its original landscape had an opportunity to migrate onto neighboring territories (perhaps, by pressing the weaker inhabitants out of there), this could permit it to maintain provisionally its previous ways of life. Very seldom, viability was restored by rejecting new technologies. Still only the episodes of "progressively" surmounted man-made crises are eventually essential for understanding the evolutionary mechanisms. As a particular crisis involved a vast region that was highly saturated with diverse cultures (the redundant variety rule), its inhabitants managed to find a radical way out of the deadlock. At those stages, selection of societies and value-norm systems compatible with grown technological power was intensified, which went together with dramatically discarding the ones unable to provide a cultural and psychological balancer for new technological might. (Actually, in some cases the catastrophic effects were moderated by cross-cultural assimilation.)

As noted earlier, no less than seven breakthroughs of global importance have taken place in the 2.5 million years of human history and prehistory. Each of them followed a large-scale conflict between technological might and social self-control, and in each case the crisis was overcome by transformations in both society-nature and intra-social relations. The breakthroughs resulted in many new developments, from growth in productivity of new economic activities to an increase in the volume of information (both collective and individual knowledge) and the development of organizational complexity. The overarching result has been the development of new stages in inter-group and in-group regulation. In fact, these stages have led to society continually digressing from its natural (wild) state. Thus, natural ecosystems have been turned into anthropocenoses and - thanks to this - the ecological niche of humans 
has been broadening and deepening. After that, however, new technologies, population growth, and the expansion of collective and individual needs have led to the next anthropogenic crises.

The link between technological potential, quality of cultural regulation and society's internal sustainability (the Law of techno-humanitarian balance) relies on evidence of case studies, and it may be considered as an empirical generalization. It implies that because of the selective mechanism, throughout history, the quality of cultural aggression-restraint have been nonlinearly (mediated by the anthropogenic crises) but progressively following the technological development. This is one of the non-trivial corollaries of the pattern, which has been subject of its quantitative verification. For this purpose, we used a distinctive cross-cultural index - Bloodshed Ratio, which is the ratio of the average number of killings per unit of time (including wars, political repressions, and everyday violence) to a population size during a given period.

Calculations show that the rate of human death from violence has been irregularly decreasing over the course of millennia, while both technological potential for mutual destruction and population densities have been successively increasing. Since the downward trend is highly nonlinear (splashes of violence correspond to the sharpening of crises) it is clearly seen only as long-time distances are considered; we may add that the decrease is mostly due to the restraint of everyday violence. This fact cannot be explained by "decreasing aggressiveness": on the contrary, concentration usually raises natural aggressiveness among both animals and humans. The only reasonable explanation is that the crucible of anthropogenic crises has made cultures multiply and perfect the procedures for aggression-sublimation into physically nonviolent social activities.

When studying the psychological aspect of this historical trend, we distinguish between the concepts of menace and danger. Menace is any factor that can damage the interests of a subject (including his physical state), while danger is the variable that reflects the relation of the menace to the subject's readiness to withstand it.

For instance, there are many more menaces in the street, in transport, at work or in public places than inside one's own flat; however, policemen, ambulance crews, and sociologists know that accidents, injuries and murders happen more frequently at home. An adult understands the menaces outside his (her) flat; therefore one is alert, concentrated and attentive. At 
home, he or she erroneously estimates relatively small menaces of being alone or among one's family or friends as lacking at all, totally relaxes, and this raises a real danger of unpleasant happenings.

Each new technology, both military and production ones, has usually carried the menace of growing destruction to geopolitical and / or natural habitat, and - after a period of euphoria - has caused social catastrophes. Nevertheless, these catastrophic dangers remained until a cultural and psychological adjustment (fitting) occurred. During this fitting process, people used to develop a proportionate appraisal of the menace. After all, norms of activity came into line with the grown instrumental potential by the mechanism of post-voluntary behavior. The essence of this mechanism (Bozhovich, 1981) by which each individual while ingrowing into current culture assimilates its mental constructs, is that the choices first imposed from outside since the early childhood and then realized through motivational conflict by volitional efforts, turn to become unconscious behavioral programs without an alternative in the adult's mind.

As a result of this process, danger decreased to an "acceptable" level, and the tamed technologies, including military ones, became a life-protecting factor. As soon as the phase of cultural and psychological fitting was completed (only after that!), the more potentially destructive a weapon was, the less murderous effect it really caused.

Thus, not a single person has perished in attacks from intercontinental ballistic missiles, which menaced the existence of mankind half a century ago (and we may suggest that no one will perish as the fitting process seems to have been completed). Atom bombs of the first generation, which had a relatively lower capacity, killed about 300,000 people including the secondary victims of delayed radiation. Tanks, artillery and bombers have taken millions of human lives. Tens of millions have fallen victim to small arms. Meanwhile, kitchen knives, axes, glass bottles, hunting rifles and other household objects used in everyday conflicts have killed more people than all combat weapons combined.

The same is true of non-combat activities. It has been shown, for instance, that if human activity at large had remained as "ecologically dirty" as it was in the 1950s, life on Earth in the 1990s would have become unbearable (Yefremov, 2004). However, even in the worst times, nuclear power plants 
caused less destructions and human loss in proportion to a unit of produced energy than the traditional peasants' stoves, which had regularly provoked conflagrations that burned down villages. (Rabotnov, 1992). Eventually, after a number of explosions that shocked the world in the 1970s-80s, a rather high level of safety has been achieved.

J. Piaget (1997) and his followers (Volovikova \& Rebeko, 1990) demonstrated a link between individual's intellectual and moral development. Similarly, ethnographers' observations have empirically verified the "conflict-enculturation hypothesis": a decrease in children's violence correlates with their increasing age both in Western and other cultures (Chick, 1998; Munroe, Hulefeld, Rogers, Tomeo, \& Yamazaki, 2000). However, U.S. psychologist L. Kohlberg's (1984) notion of moral development in human history as a single progressive tendency is still subject to criticism, even by social evolutionists.

Our results demonstrate that a link between the developments of instrumental and humanitarian intelligence is also present in world history, although it has been dramatically mediated by the crises. It is only thanks to its capacity to adapt the culture of self-regulation to steadily growing technological might that humankind has been able to live up until now. In the words of the Russian cultural historian, "History is the progress of moral tasks. Not doings, but just the tasks, which mankind's collective might puts before any individual. The tasks were more and more difficult, almost impracticable; nonetheless, they have been somehow fulfilled; otherwise, all should have fallen to pieces long ago" (Pomerants, 1991, p. 59).

Retrospective empirical data show the mainstreams of consecutive universal transformations, which can be traced in a kaleidoscope of cyclical processes on local, regional and global scales. One of such mainstreams is the succession in the development of cultural regulation, without which neither successive increase (respective concentration) of population nor growth in technological might and organizational complexities would be possible. With certain reservations, all of those historical vectors may be designated as progress (we find this term in late Roman texts, so it is more ancient than "evolution" or "development"). However, the synergetic version frees this classical idea from two ancestral vices: linearity (usually with strong overtones of Eurocentrism) and teleology. Progress is no longer interpreted as the aim or as move- 
ment toward the aim but as a means of self-preservation, with which the complex non-equilibrium system (society) responds to the challenges of declining sustainability.

\section{Growth and limitation of variety:}

\section{The Law of hierarchical compensations}

As noted earlier, the fact that one of the critical conditions for overcoming a crisis is the resource of variety accumulated by (natural or social) system at a relatively quiet stage, may be considered as a manifestation of Ashby's law. Here, however, we will call attention to its specification, which is important for our further conclusions.

The Law of requisite variety and its derivatives helps to explain many cases of increase and decrease in systems' competitiveness in the nonlinear world. Therewith, its one-sided interpretation has often led to misunderstanding.

The uncontrolled increase in variety beyond a certain optimum point lowers a dynamic system's control and thus decreases its effectiveness. For example, if variety were an unconditional value (as Ashby's law is sometimes interpreted), a language would not need a single grammar, the school would not need teachers of philology, and publishing houses could do without editors and proof-readers, as well as society could do without morals, penal code, traffic rules, and so on.

In fact, formal and informal regulations and negative sanctions, which take place in almost any aspect of social interaction, are aimed at the restriction of varieties in behavior and even in thinking; without them society is likely to lose its viability. This also takes place in criminal communities, which have their own norms, those that strongly restrict the freedom of choice and, in certain aspects, reproduce the normative system of the archaic societies (Samoilov, 1990). Nature has also produced its complex mechanisms to prevent boundless increase in the variety of species and behaviors.

Facts of this kind are hardly reconciled with Ashby's law if one sees it exclusively as the demonstration of the success of variety. We studied this question in the 1980s, together with the specialist in Information theory E. Sedov. We tried to work out correlations in the amount of variety for systems of any kind: from cosmo-physical to cognitive ones, and to evaluate the dynamic of those correlations in the evolutionary processes. 
After the untimely death of Eugene Sedov (in the last weeks of his life he developed a mathematical model to describe these correlations), in the editorial preface to his posthumously published paper (Sedov, 1993), I suggested giving the pattern his name - Sedov's Law, or the Law of hierarchical compensations. My general formulation is as follows: the increase in variety on the upper level of a hierarchical organization results from the restriction of variety on the lower levels, and inversely: increase in variety on the lower level destroys the upper level of an organization.

The Law of hierarchical compensations is congruent in both subject and volume with the Law of requisite variety and is an indispensable complement to it. Illustrations abound in all spheres of objective and mental realities. Let us consider a few examples.

A hypothesis in Cosmology claims that there was a phase transition from multidimensional space to four-dimensional spatiotemporal continuum at the early stage in the evolution of the Universe; historically, this was perhaps the first act of restriction, which made possible the increasing variety of structures. Such transitions then multiplied at the rate of acceleration and branching of the evolutionary processes. On Earth, restriction of the varieties on the subcellular and molecular levels of living matter entailed the multiplication of forms on the supra-cellular level. The eukaryotes' increasing variety was furnished by the unification of their forms of metabolism as opposed to those of the prokaryotes. A general premise for the increasing biodiversity has been the relative unification of physical conditions on Earth under the influence of living matter; subsequently, restraints on biodiversity became a necessary condition for social and cultural diversifications.

Similar dependence is manifested in all spheres of social activity. For example, a restriction of phonemic combinations in any language is necessary for the construction of words, restraint of the syntactic combinations is necessary for the construction of phrases, etc.; this has historically led to the generalization of linguistic rules. Market development was brought about by the use of the generally accepted commodity equivalent of gold, which was subsequently replaced by still more abstract equivalent, the paper banknotes secured by gold, and actually by credit cards to substitute the banknotes. The development of science also employs such simplifying generalizations, which implicitly contain a great number of recorded facts, causal links, reliable judgments and forecasts, as well as guidelines that may be deduced from them. And these, in turn, exclude many other facts and 
hypotheses. The complication in social organizations has been each time attended by new moral, legal and other restriction: all kinds of laws, directions, and rules. A.F. Hayek (1990) indicated that as far as those rules limit the choice of the means, each individual may use to realize his intentions, they immensely amplify the choice of the aims one can try to achieve.

Inversely, as soon as the grammatical regulation is abolished, a language degrades, impeding mutual understanding, dismembering linguistic community and interrupting collective activities: see the Bible story about the Tower of Babel. Cancellation of traffic rules amplifies the individual choices (i.e. variety), almost automatically augments accident rate and finally destroys the entire traffic system. In paleontology, one of the "phylogenetic rules" formulated by E.D. Cope (1904) states that any biological group has usually increased its taxonomic diversity just before extinction...

The Law of hierarchical compensations helps in a thorough treatment of some practical problems of modernity regarding global ecology and cultural policy.

\section{The specificity of modern crisis: "Knowledge-enabled destruction"}

Half a century ago, many Europeans and Americans did not believe that the $21^{\text {st }}$ century would come, and there were strong reasons to doubt. The proliferation of nuclear weapons and missiles made the menace of global catastrophe very real, particularly by the 1960s. Besides the threat of a direct nuclear war, there were military load trials, which contaminated the atmosphere, soil and hydrosphere, collateral effects of the peaceful nuclear power engineering, destruction of nature through industrial contamination by the developed nations, and demographic explosion in the Third World.

After hard diplomatic battles, the Partial Test Ban Treaty (1963) became a landmark in the development of world ecological consciousness. Even those nations that rejected the Treaty (France and China) had to gradually reduce their nuclear weapons testing under the pressure of world public opinion. Subsequently, the naïve belief in the unquestioned safety of nuclear power plants was replaced by recognition of their menace, and resulting safeguards have radically lowered the danger of unpremeditated (without terrorist provocation) accidents. Local, regional, and global 
arrangements related to ecological problems have had impressive effects. Inter-state coalitions, not aimed against any outside enemy (a dream of Humanists in the Renaissance and the Enlightenment), have become a sign of our epoch. Energy-saving psychological attitudes have involved many spheres of production and everyday activity while giving additional impulse to the development of new information technologies.

Breakthrough in the political consciousness occurred because of the compromise solutions to the Caribbean, the Berlin and the Middle East crises. People saw evidence to the politicians' capacity to abstain from using the most destructive weapons, and this abated the catastrophic expectations. There are obvious signs that global society's cultural and psychological fitting to atomic power had been successfully completed by the end of the $20^{\text {th }}$ century, and after that "classical" nuclear weapons finally transformed from the tool of aggression into the tool of deterrence. Humans learned to coexist with ballistic missiles as well as they had tamed (in chronologically descending order) firearms, steel, bronze and distant (like bows and the like) weapons, each of which threatened humanity with social degradation in earlier times.

Nevertheless, we should also consider the other side of the coin. Mankind managed to escape a nuclear catastrophe in the second half of the previous century at the price of channeling the global contradictions into the riverbed of almost continuous local wars. Up to $50 \mathrm{mil}-$ lion people perished in the total sum of those wars (1946-1991); yet, this period of world policy is usually referred to as Cold War in the context of expected (in the worse scenario) billions of victims and also thanks to the fact that unlike the two previous world wars the real victims were dispersed in space and time. Unfortunately, people had not yet learned to live without "hot" wars.

The situation had rapidly changed by the beginning of the $21^{\text {st }}$ century. Today, although the global danger of "classical" nuclear weapons has lowered (thanks to the fitting effect), the real danger has shifted to another sphere.

As technologies develop, social internal sustainability depends more and more on individual actions: this is a direct corollary of the technohumanitarian balance model. It seemed, fifty years ago, that humankind had reached the peak of this historically increasing link, as far as its existence depended on several hundred persons with access to nuclear "buttons." Now we can see that it was not yet the height. 
At the turn of the $21^{\text {st }}$ century, the U.S. scientist and computer engineer B. Joy (2000) suggested that the epoch of weapons of mass destruction was changing into the epoch of knowledge-enabled destruction. On the one hand, advanced technologies like mini-bombs, nanotechnology, robotics, and genetic engineering (which have their far-reaching destructive options), are becoming cheaper. On the other hand, mass access to education and information is penetrating nations, classes and religions, and practices of terrorism are becoming highly sophisticated. As a result, modern weaponry is becoming more and more available, slipping out of the control of nation-states and their responsible governments and falling into the hands of particular corporations, groups and "brilliant" individuals who are not burdened with political responsibility or the virtue to forecast complex long-term consequences.

Under such conditions, local conflicts no longer serve as an escape value for global catastrophe as they did in the $20^{\text {th }}$ century. Calculations demonstrate that the level of physical violence in the modern world has fallen to an unprecedented level: for example, according to the data from the World Health Organization, the number of murders in the year 2000 (this includes political repressions, armed and everyday conflicts) was smaller than the number of suicides (Krug, Dahlberg, Mercy, Zwi, \& Lozano, 2002). At the same time, modern individuals' sensitivity to violence has grown significantly, which creates a popular illusion of growing violence; what is still more important, its social price has grown as well. The multiplying technologies of terror are "delocalizing" war conflicts and making each one fraught with global after-effects as never before.

Up to the present day, the perfection of cultural self-regulation has been accompanied by dramatic elimination of social systems that have been unable to restore the broken balance. The Law of techno-humanitarian balance also admits the possibility of the crash of our planet's civilization under the weight of its own technological might. Today, we see an unparalleled rate of sharpening global problems on the one hand, while on the other, there is an unexampled velocity of information diffusion and processing, that is increasing societies' ability to undergo dynamic transformations. Accordingly, the key question of the modern epoch is whether or not our planet's civilization remains capable of improving its external and internal control as a reliable counterbalance to the accelerating growth of technologies. 


\section{Cosmic perspectives of intelligence and universal natural selection}

Theoretically, in the phase of instability, there are more than two (usually about seven) scenarios (attractors) of a complex system's further development; this is called bifurcation, or more accurately, polyfurcation, in Synergetics. As to the actual global situation, it is easy to describe a set of scenarios that lead to the crash of world society and the end of evolutionary processes on Earth. It is more important to outline the scenario that entails a new sustainability. Here, ignoring many details, we will consider the universal aspect of the issue.

In the $19^{\text {th }}$ and early $20^{\text {th }}$ centuries, German and Russian "cosmist" philosophers (G. Fichte, A. Humboldt, N. Fedorov and K. Tsiolkovsky) saw a universal perspective of civilization in boundless diffusion of the "shock wave of intelligence" outside our cradle planet. Those prospects sharply conflicted with the naturalist worldview, and their authors were subject to mockery. However, our generation of the late $20^{\text {th }}$ century witnessed the human flight into space. What is still more significant, the post-classical methodology unlike the classical natural science admits the possibility in principle that intelligence can become a factor in cosmic development.

As a psychologist, I have written more than once on this subject, arriving at my conclusions by extrapolating data about the evolution of intelligence, as well as heuristics and gestalt-theory. In the new constructive paradigm we find out that boundaries imposed on engineering by physical laws are surmountable by a change of the cognitive metasystem. Specifically, those constructs of the problem situation, which were uncontrollable constants inside one model, become manageable variables within a more complex meta-model (Nazaretyan, 1991; 2004; 2005b). Therefore, there are no absolute limits for intelligence-induced management of mass-energy processes, and a potential perspective of intelligence is linked to its expanding influence upon cosmic evolution.

Similar conclusion was substantiated from the point of view of modern natural science by U.S. physicist D. Deutsch (1997).

"Neither our theory of stellar evolution nor any other physics we know" gives any reason to restrict the potential influence of life on the cosmic processes, Deutsch writes. "Throughout our Galaxy and the multiverse, stellar evolu- 
tion depends on whether and where intelligent life has evolved. $<\ldots>$ The future history of the universe depends on the future history of knowledge. $<\ldots>$ When we apply our best theories to the future of the stars, and of the galaxies and the universe, we find plenty of scope for life to affect and, in the long run, to dominate everything that happens, just as it now dominates the Earth's biosphere" (pp. 183-186).

Deutsch also appeals to the "Turing principle": there is no upper limit to the virtual-reality generators that will actually be built somewhere in the multiverse; in other words, opportunities for intellectual control are boundless. Therefore, if the intelligence descending to Earth's civilization does not achieve control over Metagalaxy processes (possibly, because of our self-destruction), someone else will do it - "presumably some extraterrestrial intelligence" (p. 353)...

The Turing principle in Deutsch's version develops the well-known system theory principle of realization of all the possibilities (G. Simpson (1949, p. 160) also called it "opportunism of evolution"): any event that can occur in the system does really occur. The Mendeleev Table is based on this principle, and physicists proceed from the same principle in their search for the particles, which are theoretically possible, etc.

Having acknowledged as possible and therefore liable to realization both cosmic development of intelligence and its self-elimination, we see an obvious paradox. To solve the paradox, we must assume multiple hotbeds of evolution in the Universe, in which all the evolutionary scenarios are embodied, including collapse of biospheres and civilizations at each of the crucial phases. This, in turn, logically implies a surmise of the universal natural selection. Evolving life systems on various planets that cannot cope with crises at one or another phase become waste products of universal evolution. Only those few that do survive reach the cosmic stage and continue the process of Big History. ${ }^{3}$

There are indirect reasons (see below) to suggest that only one of many planetary civilizations is able to develop into a factor essential on the Metagalaxy scale, and that it has not yet occurred. There are also reasons to suggest that the next polyfurcation, which leads Earth's civi-

3 In synergetic terms, those planetary systems eventually succeed, which have successively followed "progressive" scenarios, i.e. at each polyfurcation stage they have moved toward the strange attractor - the sustainable state at a higher non-equilibrium level opposed to simple attractors - regressive sustainability on a lower level of non-equilibrium. 
lization either to collapse or transition to a cosmic stage, is not a matter of fantastic futuristic thinking: this will probably happen during the lifetime of the next generation.

\section{Snooks-Panov Vertical}

In 1996, the Australian economist and global historian G.D. Snooks published calculations that showed acceleration in evolutionary processes from the origin of life on Earth to postindustrial civilization. He discovered that over the course of 4 billion years, the time between global phase transitions in biological, pre-social and social history have been sequentially shortening in compliance with a single logarithmic equation, namely that each major biological / technological transformation took only one-third of the time of its predecessor (Snooks, 1996, pp. 7982, 92-95, 402-405).

The Russian physicist A. Panov (2005), who did not know about Snooks's work, deduced a similar equation. He followed a different cultural and disciplinary tradition, used different sources (among them, the first (2001) edition of the book (Nazaretyan, 2004)), and employed an alternative and more precise mathematics. Moreover, a particular speculative assumption allowed tracing the period of logarithmic acceleration back to 10 billion years ago: to the moment of emergence of heavy elements in the Universe (inside first generation stars), which began a new mechanism of self-organization. As light elements fuse, a quantum of energy is thrown out, while to synthesize a complex molecule, energy from outside is required. Thus, competition for free energy has launched development toward organic compounds; subsequently, the accelerating process of structural complexity has localized on Earth and perhaps at other points in the Metagalaxy.

Panov first reported his result at a seminar of the State Institute of Astronomy in Moscow in 2003. The participants appraised his empirical formula as a discovery that demonstrated the unity and continuity of universal evolution. Of still more significance, an extrapolation of the hyperbolic graph-line gives a most striking result: in the near future, it becomes vertical! This mysterious formal result has been designated as the Snooks-Panov Vertical in dictionaries.

From the merely mathematical point of view, this means that the formula describing the course of events over a period of billions of years 
will become senseless several decades from now! The velocity of evolutionary transformations goes to infinity, and the intervals between phase transitions vanish. What kind of objective reality can be revealed by this formal extrapolation?

The two authors' interpretations are diametrically opposed. In Snooks's (2005) view, the line of acceleration will reach an asymptotic direction: the disproportions in social development will be overcome, and humankind will progress rapidly toward a perfect state, but never achieve it. In other words, material transformation, or economic revolution, will become continuous but stable. Although Panov $(2005 ; 2007)$ has modified his suggestions, his general idea is that the line is to acquire a logistic form and the vertical will change into a horizontal: historical development will achieve its plateau and all of the traditional phenomena like policy, wars, scientific and technological progress will be left in the past.

In my view, so far as the equation reflects a huge fragment of Big History, its "singularity point" must prospectively mark events of universal (not just planetary) importance. In other words, either the collapse of Earth's civilization or a phase transition, perhaps congruent, because of its evolutionary impact, with the emergence of living matter, will have occurred by the middle of the $21^{\text {st }}$ century. Probably, the second or "progressive" scenario implies the next spire of "digressing from the natural state" as a condition for sustainable preservation of our planetary system, penetration into super-minute and super-dimensioned spaces, so that intellectual activity, which has actually become a geological factor, is likely to reach the cosmic scale.

Just in this point, trying to see the details of the two scenarios, we are facing the problem of meaning-formation.

\section{Viability and the worldview paradigms: ideology vs. civilization?}

In history, we can find very few cases of a society restoring technohumanitarian balance by rejecting new technologies. For example, the aboriginals of Tasmania forgot bows and arrows, and the Japanese samurais refused to use firearms for three hundred years. This way of escaping from crises could only be local and temporary, however, because it made the societies defenseless against external menaces. From a strategic 
perspective, it is only the elevation of humanitarian intelligence (i.e. sociocultural regulation) to the level of technological might that has maintained civilizations' sustainability. Humans have learned to live with new technologies by accumulating the experience of anthropogenic catastrophes and perfecting their cultural and psychological behavior regulation and thus abridging the menaces that technological growth inevitably carries.

At present, the campaigns for nuclear and other disarmament are of tactical importance as they promote mass recognition of the menaces. But the dividing line between military and non-military technologies is diffusing, and mankind cannot cope with the sharpening crises (from resource deficits to genetic degeneration) without increasingly newer technologies. As before, the strategic perspective is related to cultural and psychological adjustment and, accordingly, to radical perfections in mass consciousness.

The challenges of modern technological development have resulted in a qualitatively new problem for humanity. Since the Paleolithic age, the problem of internal sustainability has been related to structuring social violence and preventing its most arbitrary and chaotic forms. As far as an urgent problem actually is to remove physical violence from social life, it cannot be solved using ordinary remedies. Advanced communication technologies contribute to solving this problem by virtualization of violent actions (Nazaretyan, 2009a), but ultimately, nothing short of radical global conscience can succeed.

Violence structuring has been essentially achieved by transferring in-group aggression outwards. For this purpose, culture has produced ideologies, which competed among themselves, replaced one another and so ensured group consolidation by creating "us" versus "them" discrimination.

The term "ideology" emerged in the end of the $18^{\text {th }}$ century: the French evolutionist $P$. Cabanis invented it for a specific scientific research into the biological grounds of thinking. His effort to develop such a discipline failed, but the word remained, and subsequently, Napoleon Bonaparte used it as a cliché to qualify infertile political speculations.

After that, false social theories that defended particular interests of a particular large group (before all, the nations) opposed to the interests of the other groups were called ideologies; in this sense the term was used by 
K. Marx and F. Engels as well. After class struggle in Europe sharpened, a new concept of "class ideologies" appeared. The new Communists introduced a paradoxical collocation "scientific ideology" implying that the historical purpose of proletariat responded to the universal purpose of humanity and therefore was based on the "objective truth."

Since the expression "scientific (or truthful) ideology" is actually out of use, the traditional understanding of ideology as a rationalization of a group political interest has been reinstated. It is in this meaning that we use the term here.

Ideology is an anti-entropy mechanism for people's consolidation in large groups by their contraposition to other people on the basis of adherence to a particular set of sacral symbols. These discriminating symbols are constructed by mythologization of some real or fictitious events, persons, figures of speech and visual images saddled with mystical qualities and senses. The practices of the latest centuries have shown that, given a psychological disposition, any constructs may become subject to a procedure of mythologization. In this way, nation, class, materialism, atheism, democracy or market may serve as sacral symbols, as well as god, faith or king. What is inherent in any ideology is a more or less accentuated religious (or quasi-religious) kernel: consolidation of the "co-religionists" in joint rejection of the "infidels"; accordingly, real or potential war remains the immutable companion of the ideological worldview.

The perfection of cultural regulation for restoring techno-humanitarian balance at the crucial phases of history has usually included amplification of group identities. Thus inter-tribal hostility in the Paleolithic gave way to multi-tribe consolidation (chiefdoms) of the Neolithic, as people learned "for the first time in history how to encounter strangers regularly without attempting to kill them" (Diamond, 1999, p. 273). In the Bronze Age, by further military conquests some of the chiefdoms consolidated into the first multi-ethnic city-states, which viewed other city-states and older chiefdoms as enemies: "all humanity remained in the condition of perpetual and most frequently armed opposition between the societies" (Diakonov, 1994, p. 29).

As steel weapons were considerably cheaper, lighter, and more durable than the ones made of bronze, they radically aggravated the bloodshed, and to maintain viability of the leading societies, the Axial Revolt 
(800 - 200 B.C.) transformed the system of political values over an immense geographical area from Judea, Persia and Greece to India and China. Enemies learned to see each other as human beings, understand, and sympathize and no longer evaluated their generals' prowess by the number of killings and destructions. Mythological thinking oriented towards the idea of heavenly penalties for violation of social norms partly made room for critical thinking and moral of individual responsibility. Therewith, formation of the first empires stimulated the next amplification of the community scale that one could identify as "mine" versus "hostile."

The ideas of collective humanity started to take shape in the Axial Age. But those ideas proved to be too refined for the slaves and barbarians who overflowed the historical scene on the wane of the first wave of the Axial Age and who could not conceive the world without a Lord or a Chief. Those philosophies that rejected both human's submission to the man-like heavenly power and group confrontations were dislodged to the periphery of spiritual culture as "redundant varieties." The World religions, which appealed to blind faith, mystical fear and hope proved to be much more consonant with the times. Instead of the tribal and state demarcations, humans were divided by confessional affiliation. "He who is not with Me is against Me"; "I came to bring not peace but a sword", Jesus Christ said (Math. 12:34, 12:30). Muhammad developed the idea: "When ye meet the Unbelievers, smite at their necks" (Quran 47:4). In India, Krishna worship and Buddhism with their humanist-like orientation were ejected by the eclectic and confrontational Hindu ideology (Kanevsky, 1998; Alaev, 2007).

The spread of the World religions enlarged the scale of group identifications again, even compared to the imperial communities. At the same time, the tolerance for adherents of different faiths "completely remained in the past" (Diakonov, 1994, p. 70) and "fanaticism in war, of the type [that] drove recorded Christian and Islamic conquests, was probably unknown on Earth until chiefdoms and especially states emerged" (Diamond, 1999, p. 282).

The fanaticism of religious wars became indeed a whip for the Europeans in the Late Middle Ages because of the development of firearms. About $80-90 \%$ of adult male population perished in Central Europe during the Thirty Years' War. The Westfall Peace Treaty (1648) and its resulting political system saved Europe from most sanguinary religious 
(or quasi-religious) wars for the next 266 years. However, weakening religious delimitations were replaced by the ones based on nation or class: ideology remained an attribute of the social mind, and wars remained an attribute of social existence.

Both war and production technologies of the second half of the $20^{\text {th }}$ century extremely uncovered the menace of global catastrophe and required non-confrontational interstate and interclass coalitions to save our civilization. However, the conception of "universal values" has also accreted with ideological accents becoming in certain cases an instrument for economic, political and military pressure. As a protest against Westernization, multiple theories of "regional civilizations" have developed on the opposite flank, and here we find masked national and religious fundamentalism.

It is important to note that until recently both ideologies and wars have been not only immutable but also indispensable factors in social existence and development. It is no mere chance that only those religious doctrines were really in demand which provided politicians with ideological motivation of inter-group hostility. Early Christians hated "pagans," destroyed antique temples, broke statues with stones, killed philosophers and looted marketplaces (Gaev, 1987), but considered the usage of combat weapons sinful. Still, once political power was in their hands, they developed the conception of "sacred" wars, for which St. Augustine found plenty of authority in the Bible.

Since that time, Christian Church has never condemned war as such as a sinful action (Contamine, 2003), but more than once has censured pacifists for their "heretical" appeals. Logically, in "them versus us" matrix, the only effective technique to prevent or suppress a particular war is the transfer of aggression onto a common enemy; this technique has been widely exploited by religious authorities. Therewith, if the influence of a certain (religious or quasi-religious) ideology enveloped vast territories, it soon fell into hostile heresies and sects full of ever more spiteful mutual hatred.

We should also keep in mind that both ideologies and wars respond not only to social needs but also to intrinsic functional needs of individuals, so that the emotional factor has encouraged their regular reproduction as well. Psychologists who investigate the opportunities to remove violence from social life have repeatedly demonstrated that spiritual needs are more easily satisfied within a religious or quasi-religious 
context, especially in case of intensified inter-group conflicts, than in a secular and peaceful context (Lorenz, 1981; Rapoport, 1993; May, 1972; Audergon, 2005; Nazaretyan, 2008). Affiliation and a sense of security, sympathy and self-sacrifice, thirst for immortality and for the meaning of life often move the masses to support the most aggressive ideologists and politicians. The unconscious drive to tap strong and ambivalent affective experiences, which are excited by an armed conflict, is so deeply interwoven in the human emotional fabric that all kinds of substitute activity developed in culture (art, rituals, sports) have been able to inhibit its actualization only provisionally. Sooner or later, the craving for the "not for fun" passions is intensified, and individuals feverishly seek its "rationalization."

Those phases in the oscillatory dynamic of mass sentiments are spectacular for ideologists. They feel by their internal experience that the inertia of mythological worldview has not been eradicated by millennia of civilization. The burden of individual responsibility is distressing, and an adult, like a child, feels more comfortable under the auspices of an all-powerful Lord (or Father) who can always punish them and embrace them and lead them down the Road of Truth. A sweet sensation of dependence on Authority is the emotional background of infantile and slave mentality.

The question of whether religion is an adaptive mechanism or a kind of a "virus" in the human mind has been intensively discussed of late in evolutionary ethics (Dawkins, 2006; Boyer, 2008; Norenzayan \& Shariff, 2008; Markov, 2009). The synergetic approach provides some amendments to this discussion. The anti-entropy mechanism of religious and quasi-religious ideologies has played a stabilizing role throughout millennia. Nonetheless, by the Law of delayed dysfunction, it is becoming counter-productive at our new historical stage, so that the explosive mixture of mystical impulse with fatal rationality of modern weapons is threatening to blow up global civilization. Insufficient awareness of the menace increases the danger of planetary collapse (see the concepts of "menace" and "danger" above).

This is a dramatic collision-point of modernity. The humanitarian counterbalance to rapidly developing technologies urgently demands the emancipation of our mind from religious and ideological crutches (otherwise, modern society is doomed), but without those crutches humans feel uncomfortable. We have to suggest that in the observable fu- 
ture either the human (post-human? man-machine?) mind will outgrow the inertia of an ideological worldview or the ideologically-minded humanity will destroy civilization.

From there, our evaluation of the global perspective depends on the answers to the following questions:

First: Is conclusive meaning-making in an entirely secular context feasible in principle or not? Having accepted that in our Universe meaningmaking is anyhow tied to (quasi)religious beliefs through the logic of prior knowledge or inbred gestalts (beyond such beliefs life's meanings eventually fail), we cannot escape a sad deduction. Namely, there is a certain limit for technological development after which civilization on any planet destroys itself, and the evolution on Earth is approaching this limit. If this is so, then the cosmic perspective of intelligence, which is theoretically allowable from the point of view of physics, synergetics and heuristics, is shortened by the laws of cultural anthropology and social psychology, as far as the opportunities of outward control exceed the range of psychological self-regulation. As a result, the developments of life and intelligence look like the side effects (epiphenomena) in a particular stage of the evolution of the physical Universe, ones that can never play an essential role in the process. After all, long-term universal prospects are reduced to the physical scenarios (including natural deaths of planets, stars, galaxies and particles), and the "silence of Cosmos" gets a most trivial explanation: there can be no intellectual activities outside some local spheres.

This conclusion corresponds to the methodology of the Anthropic cosmological principle in its so-called weak (non-teleological) version. Had one of the basic constants of the physical world slightly differed (for instance the ratio between the masses of proton and electron), protein molecules could not have emerged. In the "weak" version, it is conjectured that a conscious observer emerges only in those universes of the infinite Multiverse, which by chance get all of the constants happily combined.

We do not know if the range of freedom in thinking (imagination) is limited by the prior mental constructs determined in turn by the physical properties of the Metagalaxy, or to what extent it is. But we do know that the specific weight of mental realities in the aggregate determination of material processes has been steadily increasing throughout the history of life and society: this is demonstrated by the huge mass of empirical data on evolutionary biology and historical ecology. As a result, the mental compo- 
nent is actually becoming the determinant factor in further development. From there comes our assumption: if the field of meaning-making has an immanent boundary, further evolution may be excluded because of limited ability to restore the techno-humanitarian balance.

Gestalt-psychologists were among the most confirmed adherents to the Kantian doctrine of prior ideas in the $20^{\text {th }}$ century science. However, there are reasons to suppose that their experimental results were based on an insufficiently representative sample of subjects. This was shown in the 1930 s by A. Luria and his pupils in Middle Asia and later on by his followers in Africa (Luria, 1974; Cole \& Scribner, 1974). Their researches demonstrated that the adults, who had not gone to European schools, did not have either inherent images of geometric figures or instinctive sense of syllogism, etc. If so, our supposition about prior closure of the strategic meaning-making inside (quasi)religious constructs may be premature: it is merely a strong historical momentum, one that is surmountable in principle. In this case, humanity's "full age" in the future "nonecclesiastical world," forecast by the German philosopher and priest D. Bonhoeffer (1997) in the first half of the $20^{\text {th }}$ century, might be achievable.

If we answer the first question in the affirmative, it is appropriate to suppose that the capacity to develop and adopt the strategic life's meanings free from (quasi)religious context is the precondition for the cosmic diffusion of any planetary civilization at this stage of the universal natural selection. In this case, the "silence of Cosmos" may testify to the fact that either no civilization in the Metagalaxy has yet reached the relevant stage of development or none of those that have reached this stage, could have passed the maturity test (the test of secular meaning-making). From here, we face the second question: will civilization on Earth achieve its intellectual full age before it irreversibly slides down a precipice to selfdestruction or not?

The psychological specification about universal natural selection is that an intellectual agent, whose self-identification is attached to a particular nation, religion or class, cannot become universal and rise to a cosmically significant level; as a result, he is unable to escape self-destruction beyond a certain level of technological might. To achieve universality, intelligence is to be highly individual and, therefore, cosmopolitan.

What might be the content of meaning-making strategies and the new worldview reference points is an important issue for multi-disciplinary 
discussions. There are reasons to hope that the elements of strictly secular and critical worldview have been accumulated in world philosophical thought during the latest 2500 years. They are there in the doctrines of the Greek and Chinese philosophers in the origin of the Axial Age, of the Arab Zindiqs (Atheists) of the $10^{\text {th }}$ century C.E., of the Renaissance humanists, of the Progressives and the Enlighteners in the Modern Era, of the pantheist materialists, the agnostics and the skeptics, and others.

These great thinkers, who tried to meet the challenges of their own epochs, sought the background for morality free from otherworldly sanctions and searched for a direction for life activities outside the framework of individual existence, but without the appeals to celestial sovereigns or the collective totem, of spirituality without mysticism and of solidarity without confrontation. Although their ideas were not adequately appreciated by the majority of their contemporaries, they are now claimed by history, and the "redundant variety" of those ideas may constitute a framework for the new worldviews.

The dissemination of computer networks, accompanied by the development of their mechanisms and languages is a material factor in loosening religious-ideological attitudes. Under its influence, linear ("bookish") thinking is being superseded by the mosaic and palliative thinking, which is less prone to dogmas. The frontiers of state, confessional and regional "civilizations" are being washed away: the intensity of individual contacts is becoming less and less shaped by geographic location, as well as one's contacts hardly depend on residence in a megalopolis with good telecommunication.

This process entails a networked organization of the world community, limitation of variety and the dying out macro-group cultures (national, confessional, and class) that are always constructed according to "them versus us" scheme. By the Law of hierarchical compensations, the unification in basic values and norms is a premise for a growing diversity of micro-group cultures, which are built on actual common interests and repeatedly interlaced among themselves; such cultures are therefore non-confrontational and do not need ideological braces.

Antagonism of the two trends - the resuscitation of fundamentalism and "religious Renaissance" on the one hand, and globalization and washing out of the macro-group demarcations on the other - is the leitmotif of our modern stage in world history. The destiny of Earth's civilization may essentially depend on how this antagonism will be resolved. 
It goes without saying that the survival scenario does not foreshadow the idyll: realistic scenarios differ from utopian ones in their capacity to foresee the price for success. Progress will bring, as always, an increasing stream of new global problems related to the next spire of the "digression from the natural state," development of genetic engineering, manmachine intelligence, and so on. The multidimensional conflict between the artificial and the natural may become the pivot of global problems by the middle of the $21^{\text {st }}$ century, and the next decades will be marked by a cardinal review of such fundamental categories as life, death and immortality, human and machine, solidarity, mind and intelligence...

\section{References}

Alaev, L.B. (2007). Istoriâ Vostoka [The History of the East]. Moscow: ROSMENN. Ashby, W.R. (1964). Introduction to Cybernetics. London: Methuen.

Audergon, A. (2005). The War Hotel. Psychological Dynamics in Violent Conflicts. London and Philadelphia: Whurr Publishers. Books.

Bonhoeffer, D. (1997). Letters and Papers from Prison. N.Y., London: Touchstone

Boyer, P. (2008). Religion: Bound to Believe? Nature, 455, 1038-1039.

Bozhovich, L.I. (1981). Značenie kul'turno-istoričeskoj koncepcii L.S. Vygotskogo dlâ sovremennyh issledovanij psihologii ličnosti [The Meaning of the Cultural-Historical Conception by L.S. Vygotsky for Modern Researches in Personality Psychology]. In V.V. Davydov, V.P. Zinchenko, V.M. Munipov, \& L.A. Radzikhovsky (Eds.), Naučnoe tvorčestvo L.S. Vygotskogo i sovremennaâ psihologiâ [Scientific Creation of L.S. Vygotsky and Modern Psychology] (pp. 24-30). Moscow: IGPP.

Chick, G. (1998). Games in Culture Revisited. Cross-Cultural Research, 32 (2), 185-206.

Cole, M., \& Scribner, S. (1974). Culture and Thought. A Psychological Introduction. N.Y., London: John Wiley \& Sons, Inc.

Contamine, Ph. (2003). La Guerre au Moyen Age. Paris: Presses Universitaires de France.

Cope, E.D. (1904). The Primary Factors of Organic Evolution. Chicago, Ill.: Open Court Publications.

Dawkins, R. (2006). The God Delusion. N.Y.: Private Eye.

Deutsch, D. (1997). The Fabric of Reality. London, N.Y.: Allen Lane, The Penguin Press.

Diakonov, I.M. (1994). Puti istorii. Ot drevnejšego čeloveka do naših dnej [The Paths of History. From the Ancient Humans to Our Days]. Moscow: VL RAN. 
Diamond, J. (1999). Guns, Germs, and Steel. The Fates of Human Societies. New York, London: W.W. Norton \& Company.

Gaev, G.I. (1987). Hristianstvo i "âzyčeskaâ kul'tura" [Christianity and the "Pagan Culture"]. Ateističeskie čteniâ, 16, 24-35.

Hayek, F.A. (1990). The Fatal Conceit. The Errors of Socialism. Vol. I. Chicago: The Univ. of Chicago Press.

Joy, B. (2000). Why the Future Doesn't Need Us. Wired, April, 238-262.

Kanevsky, L. (1998). Kannibalizm [Cannibalism]. Moscow: Cron-Press.

Klix, F. (1983). Erwachendes Denken. Eine Entwicklungsgeschichte der menschlichen Intelligenz. Berlin: Deutscher Verlag der Wissenschaften.

Kohlberg, L. (1984). The Psychology of Moral Development. N.Y: Harper \& Row.

Krug, E.G., Dahlberg, L.L., Mercy, J.A., Zwi, A.B., \& Lozano, R. (Eds.). (2002). World Report on Violence and Health. Geneva: World Health Organization.

Lorenz, K. (1981). Das sogenannte Bose. (Zur naturgechichte der agression). Munchen: Dt. Taschenbuch Verlach.

Luria, A.R. (1974). Ob istoričeskom razvitii poznavatel'nyh processov. Eksperimental'no-psihologičeskoe issledovanie [On the Historical Development of Cognitive Functions. An Experimental Psychological Inquiry]. Moscow: Nauka.

Markov, A.V. (2009). Religiâ: poleznaâ adaptaciâ, pobočnyj produkt èvolûcii ili "virus mozga"? [Religion: A Useful Adaptation, a Side Product of Evolution, or a "Brain Virus"?]. Istoričeskaâ psihologiâ $i$ sociologiâ istorii, 2 (1), 45-56.

May, R. (1972). Power and Innocence. N.Y.: Norton.

Munroe, R.L., Hulefeld, R., Rogers, J.M., Tomeo, D.L., \& Yamazaki, S.K. (2000). Aggression among Children in Four Cultures. Cross-Cultural Research, 34 (1), 3-25.

Nazaretyan, A.P. (1991). Intellekt vo Vselennoj: istoki, stanovlenie, perspektivy [Intelligence in the Universe: Sources, Formation, and Prospects]. Moscow: Nedra.

Nazaretyan, A.P. (2004). Civilizacionnye krizisy v kontekste Universal'noj istorii. Sinergetika - psihologiâ - prognozirovanie [Civilization Crises within the Context of Universal History. Self-Organization, Psychology, and Forecasts]. $2^{\text {nd }}$ ed. Moscow: Mir.

Nazaretyan, A.P. (2005a). Fear of the Dead as a Factor in Social Self-Organization. Journal for the Theory of Social Behaviour, 35 (2), 155-169.

Nazaretyan, A.P. (2005b). Western and Russian Traditions of Big History: A Philosophical Insight. Journal for General Philosophy of Science, 36 (1), 63-80.

Nazaretyan, A.P. (2008). Antropologiâ nasiliâ i kul'tura samoorganizacii. Očerki po èvolûcionno-istoričeskoj psihologii [Anthropology of Violence and Culture of Self-Organization. Essays on Evolutionary Historical Psychology]. $2^{\text {nd }}$ ed. Moscow: LKI.

Nazaretyan, A.P. (2009a). Virtualizaciâ social'nogo nasiliâ: znamenie èpohi? [Virtualization of Social Violence: A Sign of Our Epoch?]. Istoričeskâ̂ psihologiâ $i$ sociologiâ istorii, 2 (2), 150-170. 
Nazaretyan, A.P. (2009b). On the Mechanisms of Moral Development in Evolutionary Historical Psychology. In Yu.P. Zinchenko \& V.F. Petrenko (Eds.), Psychology in Russia: State of the Art. Scientific Yearbook. Vol. 2 (pp. 72-100). Moscow: RPS.

Norenzayan, A., \& Shariff, A.F. (2008). The Origin And Evolution Of Religious Prosociality. Science, 322, 58-62.

Panov, A.D. (2005). Scaling Law of the Biological Evolution and the Hypothesis of the Self-Consistent Galaxy Origin of Life. Advances in Space Research, 36, 220-225.

Panov, A.D. (2007). Universal'naâ èvolûciâ i problema poiska vnezemnogo razuma (SETI) [Universal Evolution and the Problem of Search of Extra-Terrestrial Intelligence (SETI)]. Moscow: LKI.

Piaget, J. (1997). The Moral Development of the Child. New York: Free Press.

Pomerants, G.S. (1991). Opyt filosofii solidarnosti [An Assay on Philosophy of Solidarity]. Voprosy filosofii, 3, 57-66.

Rabotnov, N.S. (1992). S drovami v XXI vek? [Shall We Enter the $21^{\text {st }}$ Century with Firewood?]. Znamâ, 11, 195-213.

Rapoport, A. (1993). Mir - sozrevša â ideâ [Peace as a Mature Idea]. Darmstadt: Darmstadt Bletter.

Samoilov, L.S. (1990). Ėtnografiâ lagerâ [Ethnography of the Prison Camp]. Sovetskầ ètnografiâ, 1, 96-108.

Sedov, E.A. (1993). Informacionno-èntropijnye svojstva social'nyh sistem [Information and Entropy Attributes of Social Systems]. Obŝsestvennye nauki i sovremennost', 5, 92-101.

Simpson, G.G. (1949). The Meaning of Evolution. New Haven: Yale Univ. Press.

Sloterdijk, P. (1983) Kritik der zynischen Vernunft. 1. und 2. Band. Edition Suhrkamp, Fr.a.M.

Snooks, G.D. (1996). The Dynamic Society. Exploring the Sources of Global Change. London, New York: Routledge.

Snooks, G.D. (2005). The Origin of Life on Earth: A New General Dynamic Theory. Advances in Space Research, 36, 226-234.

Volovikova, M.I., \& Rebeko, T.A. (1990). Sootnošenie kognitivnogo i moral'nogo razvitiâ [The Correlation in Cognitive and Moral Development]. In B.F. Lomov \& K.A. Abulkhanova-Slavskaya (Eds.), Psihologiâ ličnosti v socialističeskom obŝestve [Psychology of Personality in the Socialist Society] (pp. 81-87). Moscow: Nauka.

White, G.F. (Ed.). (1974). Natural Hazards: Local, National, Global. New York, London, Toronto: Oxford Univ. Press.

Yefremov, K. (2004). Putešestvie po krizisam [A Travel around the Crises]. Licejskoe i gimnazičeskoe obrazovanie, 3, 5-6, 68-70. 